\title{
ASPECTS OF VISUAL ART
}

\author{
PhD Daniela Barbulov Popov
}

Faculty of Arts and Design, West University of Timişoara, E-mail: diiv1@open.telekom.rs

\begin{abstract}
Development of technology and visual communications implicates the necessity of the school subject visual art through which it is possible to present to the pupils the most important art pieces and achievements from the domain of visual communications which will form their opinion about aesthetics and will influence their further art development. Learning about art and through art develops different forms of thinking and creativity. In the first part of this work, through curriculum components, the author's wish is to present key elements for the school subject of visual art. In the second part of the work, the wish is to point out the importance of creative approaches to education, and also the possibility of different media of artistic expression by which it could be communicated to the youngster's different instructional content on much accessible way.
\end{abstract}

Keywords: visual art, curriculum, education

\section{Introduction}

Encyclopaedia Britannica defines the notion of art as the modes of expression that use skill or imagination in the creation of aesthetic objects, environments, or experiences that can be shared with others.

Charles Batteaux in the 1746 was the first to implement the term of beautiful art which, in his opinion comprehend the following elements: dancing, floriculture, sculpture, music, poetry, architecture and eloquention. Later on, this division would undergo several changes by adding or eliminating some elements depending on different authors. Actual division of beautiful arts comprehends: architecture, dance, sculpture, music, painting, literature, seventh art refers to film while the eight to photography.

The word art itself can refer to different things: it can be a study of creative skill; process of usage of creative skill and experience that public has in interaction with creative skill. The purpose of pieces of art can be: to communicate some idea (spiritual, philosophically motivated art) to explore the nature of senses, to create the felling of beauty or to make strong emotions. Creative arts are often divided on special categories as decorative arts, visual arts etc.

Visual culture refers to aspects of visual expressing no matter their use within material culture. The notion of visual art has been introduced in the last decades of XX century because of the necessity to define new media in art expressing as conceptual and video works. Here the notion of "visual art" is used to show the unity of art and visual culture ( $N$. Makuljević ,2006) ${ }^{[5]}$.

\section{Visual art - school subject}

If we look back to the explications of theoretical basis on which states establish education and instruction from art domain, we can notice that in the mentioned theoretical basis it is pointed out that dealing with art and studying through art influences intellectual and emotional development, that it has an important role in expressing and interchanging cultures, in building personal and cultural identity and in transmitting values and ideas, that it increases processes of thinking and pupils' personal confidence (A. Joksimović, 2008) ${ }^{[1]}$.

With the subject of visual art the most important works and achievements of art from the domain of visual communications can be shown to the pupils and that will form their view on esthetics and influence their further art development.

The majority of states reassessed and modernized their aims, outcomes and instructional contents of visual art, in regard to the time in which we live and the development of technology and visual communications, this subject becomes almost necessary. In this work, through curriculum components, the author wishes to present key elements for the school subject visual art.

The expression curriculum is most often mentioned in relation to the changes in educational systems and teaching as a new term for instructional plan and program. If we refer to the content of this notion there are several differences: beginning from the opinion that curriculum is an attempt to unify the disunity of subjects through the curriculum construction, that it is school life and program, dynamic activity system, or maybe to the most 
extended determination in USA that equalize this notion with the European comprehension of didactic content (V. Voskresenski,2010) ${ }^{[2]}$.

Curriculum gives advantage to teaching aims and outcomes. Outcomes (expected achievements) represent instructional fulfilled results and define knowledge, abilities, movements and values which a pupil has to acquire and develop during the teaching stage. Depending on them, there are going to be determined other key elements of the teaching course as: contents, strategies - methods, media, work forms, and didactical role of pupils and teachers, too.

In earlier works there have been identificated basic structural components of a curriculum (D.B.Popov,2012) ${ }^{[3]}$ :
- Assumptions of conditions
- Aims and outcomes
- Thematic unit and content
- Basic notions
- Pupils and teacher's activities
- Instructional methods
- Forms of instructional work
- Evaluation

The component assumptions of conditions refers to: psychological, social, cultural features of the pupil; specialist, psychological, social and culture features of teachers (primer factor for this aspect of profession is that teacher should be creator, person with high ethical values, he/she should dominate solidly pedagogic and psychological problematic, be solid organizer and creative person that is able to apply conventional work and to explore new possibilities for achieving good results, discover giftedness, talent and enable the pupil to be conscious of his/ her own abilities.); and as material conditions, studying objects, means and sources (classroom, computers, video beams, projectors, modern media for communication, web-sites, books, written and other material that could be helpful for planning quality teaching).

Aims: pupils to adopt knowledge through art, exercise memory, develop creativity, understand their own ideas and communicate with ideas and convictions of others, to understand the language and the possibilities of different media of artistic expression, enriching art expression and culture through exploring and experimenting in creativity and acquiring new theory and practical knowledge in domain of modern movements in art, culture and visual communication.

Outcomes: creative expression, developing different forms of thinking and possibilities to acquire knowledge based on judging and invention, recognizing and using visual/artistic values and possibilities of computer technology and creating conceptual solutions for free creating.

Aims and outcomes should comprehend all three areas of studying: cognitive, affective and sensorimotor.

Thematic units: drawing, painting, sculpture, graphics, architecture, computer art, graphic design, computer graphic, photography, history of art, esthetics.

Basic notions: art elements, art language, theory of form, art process, art form, media.

Teaching methods: verbal and textual, illustrative and demonstrative, practical work.

Other components and also the already mentioned ones are determined based on program content of the school subject. And we should mention that thematic units and contents develop and upgrade depending on the pupils' ages, in early grades all the arts are integrated while in older grades they are separated. Also, we should consider the fact that for some thematic units certain informatics education is needed.

\section{Including Visual arts in instructional contents}

Some forms of visual art can be included also in the content of the rest of school subjects. Modern informatics and communicational technology (ICT) through educational multimedia, Internet and other instructional digital media (multimedia manuals, dictionaries, encyclopedias) offer simulative and relevant work environment which activates pupil's senses, increases their attention and motivation. Researches made by numerous institutions (Becta, UNESCO, ISTE, etc.) indicate that adequate usage of ICT increases the quality of teaching and the results of studying (M. Ristić,2009) ${ }^{[4]}$.

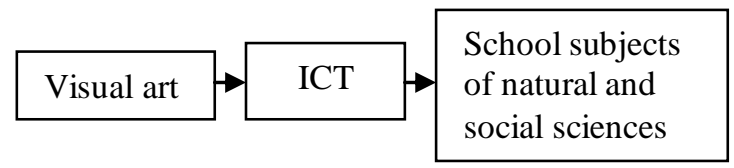

Figure 1. Relation between visual art and school subjects

Photography, video and new tendencies have been largely treated as dominating modern media for communication. The photo that takes place in the camera window, video, web and graphic design, digital art enable a large field of different forms of expression. Art features particular for new technology also make possible new forms of social interaction.

Virtual internet presentations (as, for example Virtual Field Trips in education) represent 
educational experiences of interactive research of content related to determined topics which make possible to the pupils to acquire new and to amplify existing knowledge from certain scientific domains. Doing this it is important to choose contents that are in function of realizing instructional plan and program for certain subject, depending on pupil's age (elementary or high school education).

Virtual internet presentations (360 VR interactive imaging) use modern $360^{\circ}$ photography as presentation base. 360 VR panoramas represent spherical interactive photography made from more single photographies which present space at 360 grades horizontally and 180 grades vertically. Photographies gotten this way pin together in a panorama in, so called, equidistant projection, that is afterwards converted in flash in order to get interactive character and thus enable the spectator the desired view and the spectator has the impression of virtual space. $360 \mathrm{VR}$ virtual tour represents an assemblage of more than $360 \mathrm{VR}$ panoramas, and it enables, besides the view in all directions, movement through the presentation passing from one to next panorama ${ }^{[8]}$. We will mention several:

- http://www.googleartproject.com/. This project enables the visitors to look chosen art collection from 184 world museums.

- http://mnh.si.edu/panoramas a detailed virtual tour of the Smithsonian National Museum of Natural History. In this impressive museum you can look at fossils, plants and animals, insects, rocks and minerals, archeological artifacts, too.

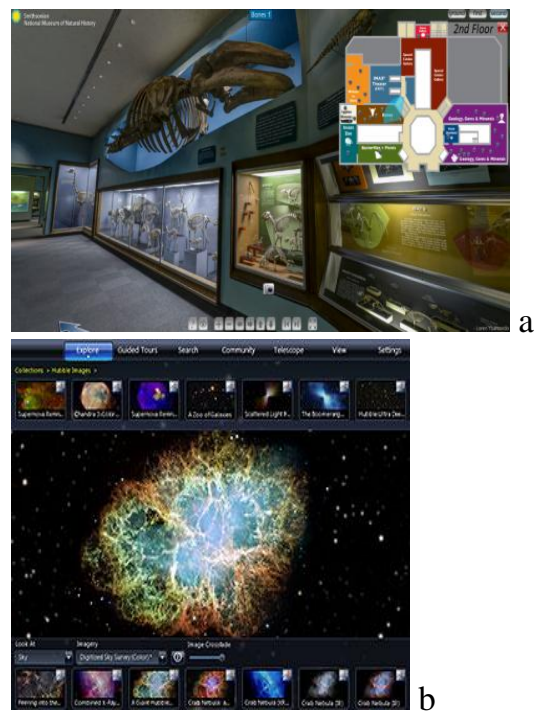

Figure 2. a) Display of one side of virtual presentation Smithsonian National Museum of Natural History, b) Display of the page of WorldWide Teleskop
- http://www.google.com/sky makes possible for us to see celestial bodies, including stars, constellations, galaxies, planets and moon surface and the Earth's moon.)

- WorldWide Telescope - software for astronomy classes, enables interactive display of Solar System and this is done collaborating with leading world observatories.

- The Virtual Body on MEDtropolis web site represents a section for virtual research of human body.

When we speak about including visual art in the content of other school subject, we should mention the structural correlation of the area of art with other educational areas. We will give an example of interaction between arts and mathematics: Digital art can be entirely made of computers or taken from other sources, as, for example, scanned photos or pictures made by softwares for vectorial graphic. Between maths and graphic art since long time ago there has been interaction, for example, through mutual interests in concepts as are the proportion and perspective that play an important role in both areas. The progress of computer technology enabled the development of different forms of digital art that allow to artists and mathematicians mutual collaboration.

\section{Conclusion}

In the time of modern visual culture, in this changed world of work, modern jobs require modern education and development of some skills and knowledge from the domain of visual art that haven't developed enough in schools, although, it is declared that artistic schooling and education have an important role, but we can't see that by the time reserved in instructional plans.

In this work, through curriculum components have been presented key elements for school subject visual art because the curriculum conception admits all teaching factors, not like the traditional planning which was directed, in the first place, to realization of teaching content. The subject visual art offers to the pupils the opportunity of training in order to understand it completely, for creative thinking, critical consideration, language understanding and possibilities of different media of artistic expression in traditional and modern context. The aims and results of this subject are directed to schooling and education, to personality cultivation through studying and dealing with visual arts because it forms numerous abilities, habits, skills, attitudes, 
knowledge, it educates the relation to oneself, to people, to history, present, future civilization, cultural heritage.

Modern informatics and communication technology through educational multimedia, Internet and other educational digital media, also offer, using the methodology of visual arts, the opportunity to communicate to pupils in much approachable way other teaching content.

The desire is that through this work, at least partially, to point out the importance of creative approaches to education, bigger presence of modern visual art in educational process, since it isn't, in most cases, comprehended by regular school programs.

\section{Bibliography}

[1] Aleksandra Joksimović, "Nastavni predmet iz oblasti Vizuelnih umetnosti u obaveznom školovanju - uporedna analiza”, PEDAGOGIJA ( UDK: 371.3), vol. LXIII, no.4, , p.605-618, 2008.

[2] Vanja Voskresenski, Kosta Voskresenski, Vesna Odadžić , »CURRICULUM AS CYBERNETIC MODEL FOR TUITION PLANNING - REFERENCE TO ELECTRICAL ENGINEERING TEACHING", Technics Technologies Education Management - TTEM (ISSN 1840-1503) , Published by DRUNPP, Sarajevo, Vol. 5 Number 2, p. 360-366, 2010.

[3] Daniela Barbulov - Popov, Vanja Voskresenski, Jovan Stepanović, Nenad Ćirković: CURRICULUM AND CYBERNETIC MODELING OF PLANNING AND REALISATION RELATED TO TEACHING IN TEXTILE SUBJECTS, Industria Textila (ISSN 12225347), Certex, vol. 63. no. 4, p. 208-212, 2012.

[4] Miroslava Ristić, “e-Učenje - Potencijali za podršku darovitim učenicima”, pregledni rad, ( ISBN 978-86-7372-114-9), 15, p.519-533, 2009.

[5] Nenad Makuljević, Umetnost i nacionalna ideja u XIX veku: Sistem evropske i srpske vizuelne kulture u službi nacije, Beograd, Zavod za udzbenike, 2006.

[6] http://pilcasopis.wordpress.com/category/ikt -u-nastavi/

[7] http://sites.google.com/site/pomocnikunasta vi/.

[8] http://www.360vr.rs/

[9] www.Charles Batteaux
[10] www.Enciclopaedia Britannica Online 